\title{
KAJIAN POTENSI ENERGI PADA SABO DAM CIBATU UNTUK PEMBANGKIT LISTRIK TENAGA MIKROHIDRO (PLTMH) DI KABUPATEN GARUT
}

\author{
Yayat Hendrayana ${ }^{1}$ \\ Teknik Sipil Fakultas Teknik Universitas Majalengka
}

yayat.hendrayana@yahoo.co.id

\begin{abstract}
Garut has enermous potential water resources that can be useful as human benefit, one of the benefit energy development water resource through conversed potential energy become electricity energy. Through existing benefit of Water resource infrastructure is needed to developed as micro hydro electric power plant (MHEPP). Technical Energy Potential study is needed to identify developed potential water resources. Design Discaharge sabo dam Cibatu is $17.78 \mathrm{~m} 3 / \mathrm{sec}$. the discharge generete at 655 of Q measure at Sabo Dam Crest formula. Capacity power is $1,279 \mathrm{MW}$ wit head net $11.88 \mathrm{~m}$ install 2 kaplan turbine. Total revenue is Rp. 8.56 Billion per year from firs year to eight year and at 9th year to 20th year is Rp.5,97 Billion as mention by Permen ESDM n0 12 / 2014. Econmic analysis must be detail to get obvious IRR and NPV whether to get Positively investment or not on this project
\end{abstract}

Keywords : PLTMH, Discharge, energy.,

\section{Pendahuluan}

Garut merupakan kabupaten yang memiliki potensi sumber daya air berlimpah dan bisa dimanfaatkan dalam berbagai hal, salah satunya adalah pengembangan sumber daya air menjadi sumber energi melalui pemanfaatan debit dan perbedaan tinggi terjun/head. Mekanisme ini adalah sebuah sistem konversi tenaga, menyerap tenaga dari bentuk ketinggian dan aliran, dan menyalurkan tenaga dalam bentuk daya mekanik ke daya listrik. Pada tahun 2008, rasio elektifikasi di Jawa Barat hanya sebesar 64.24\%, terdapat lebih dari 154 ribu kepala keluarga yang tersebar di 16 kabupaten dan 3 kota yang belum menikmati infrastruktur listrik. Ada 4 desa di Kabupaten Garut dan Cianjur yang belum terjangkau jaringan listrik PLN (Pemda Jabar, 2011). Salah satu solusi yang dapat dilakukan adalah membuat Pembangkit Listrik Tenaga Mini maupun Mikro Hidro (PLTM/PLTMH).

Dengan memanfaatkan bangunan air yang sudah ada bisa dikembangkan menjadi unit pembangkit listrik dengan skala kecil (PLTM/H). Kajian potensi energi ini dilaksanakan untuk mengidentifikasi potensi yang dapat dikembangkan Salah satu Bangunan air yang memiliki potensi pengembangan energi untuk pembangkitan listrik di kabupaten Garut yang berada di sungai Cimanuk adalah Sabo dam Cibatu. Menurut fungsi utama sabo dam adalah untuk mengontrol sedimen, namun dengan sedikit modifikasi dapat difungsikan juga sebagai bendung irigasi, jembatan penghubung dan mikro hidro (Pengantar teknologi sabo dam, bab 4 hal iv-1). Sabo Dam Cibatu digunakan untuk mengontrol sedimen dan jembatan pengubung dan belum termanfaatkan untuk irigasi dan mikro hidro. Berdasarkan hal tersebut maka Kajian Potensi energi air di Sabo Dam Cibatu yang memiliki Debit dan tinggi terjun yang memadai maka penulis berusaha untuk melakukan Kajian Potensi Energi Pada Sabo Dam Cibatu Untuk Pembangkit Listrik Tenaga Mikrohidro (PItmh) Di Kabupaten Garut

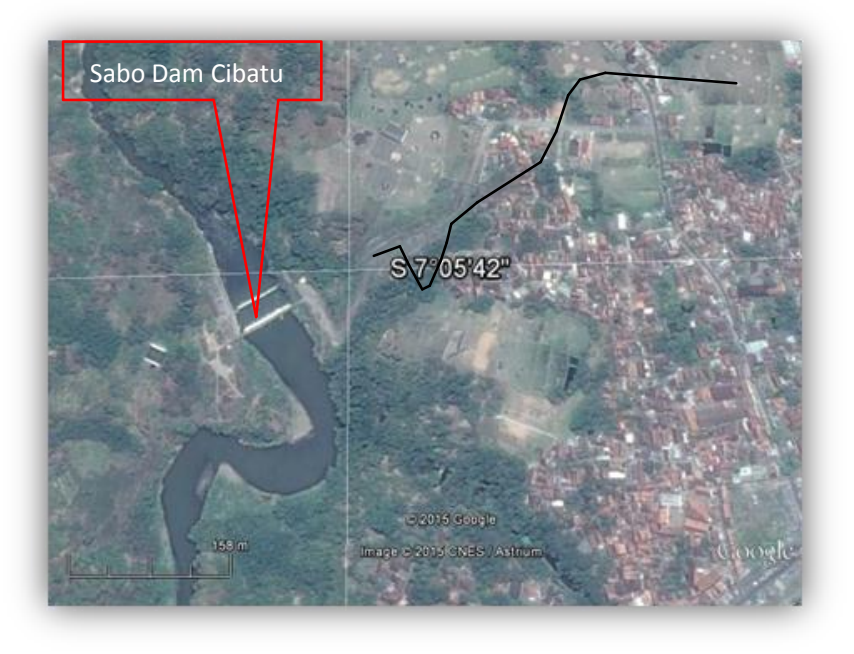

Gambar 1. Lokasi Kajian Sabo Dam Cibatu Sumber: Google Earth 2015

Lokasi kajian potensi energi berada di salah satu bangunan air yang sudah terbangun oleh pihak BBWS Cimanuk-Cisanggarung. Bangunan yang dimaksud itu adalah Sabo Dam Cibatu, yang secara geografis berada pada garis $07^{0} 05^{\prime} 42,5^{\prime}$ ' Lintang Selatan dan $107^{\circ} 58^{\prime}$ 46,4" Bujur Timur dan secara administratif terletak di 
Desa Keresek, Kecamatan Cibatu, dan desa Leuwigoong, Kecamatan Leuwigoong, Kabupaten Garut, Provinsi Jawa Barat. Lokasi ini dapat dicapai lewat jalan Provinsi Bandung - Tasikmalaya sejauh 8 km dari Desa Limbangan Timur kearah Kecamatan Cibatu dengan kondisi jalan beraspal bagus, atau lewat jalan utama Garut pada simpang Leles menuju Cibatu dengan jarak sekitar $15 \mathrm{~km}$, dengan kondisi jalan beraspal bagus.

Kegiatan Penelitan dan Kajian potensi PLTM pada Sabo Dam Cibatu ini memerlukan banyak faktor dan parameter teknis maupun nonteknis yang harus dikumpulkan dan di perhatikan. Selain itu hasil kegiatan ini dapat dijadikan dasar perencanaan rinci PLTM dan Penyusunan Program Pembangunan bagi BBWS Cimanuk-Cisanggarung dan Kebijakan Ketenagalistrikan PLN di daeah kab. Garut. Penelitian dan kajian sebelumnya yang menjadi acuan adalah UKL UPL Sabo Dam Cibatu Agustus 2009

\section{Rumusan Masalah}

Berdasarkan deskripsi diatas, maka paket-paket permasalahan pada kajian ini dapat dirumuskan sebagai berikut:

1. Optimasi Tata Letak bangunan dan unit pembangkit?

2. Optimasi Debit dalam Penentuan Unit Pembangkit?

3. Berapa tinggi jatuh Effektif yang digunakan?

4. Berapa Besar Daya Energi yang dihasilkan berdasarkan optimasi unit pembangkit?

5. Bagaimana Kelayakan ekonominya?

\section{Kajian Pustaka}

\section{Tenaga Air (Hydro Power) dan Sabo Dam}

Tenaga air atau Hydro Power Adalah daya listrik yang dihasilkan dari Pemanfaatan aliran air. Energi potensial air dari Bendungan atau air terjun diubah menjadi eneergi kinetik melalui turbin. Energi kinetik ini kemudian diubah menjadi energi listrik dengan menggunakan Generator (Penche dan Minas,1980). Tinggi jatuh air (head) sangat menentukan daya yang akan dihasilkan, karena semakin tinggi jatuh air, maka semakin tinggi energi potensial yang dimiliki oleh air tersebut

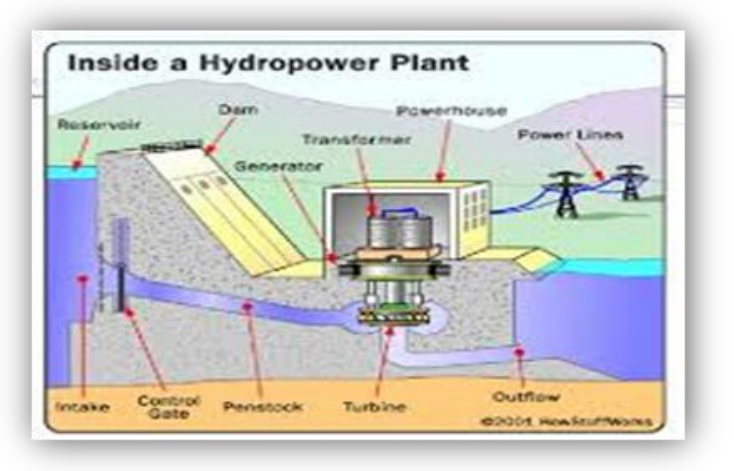

Gambar 2.Skema Dasar PLTM/PLTA Sumber: Google.com
Proses perencanaan PLTM/H biasanya hanya membutuhkan waktu satu sampai dua tahun, sedangkan Perencanaan PLTA bisa mencapai sepuluh hingga lima belas tahun. PLTM/H bisa dikelola oleh swasta maupun masyarakat desa sehingga ketergantungan terhadap pasokan listrik dari PLN bisa dikurangi. Oleh karena itu, PLTMH cocok untuk mengatasi ketersediaan listrik pada daerah- daerah terpencil (Chandra, 2009)

Sabo is a Japanese term which means erosion and sediment management. Sabo structures aim to protect lives, infrastructures, and properties from sediment related disasters in hilly and mountainous terrain. (Technical standards and guidelines for planning and design of sbao structures, department of public works and highways, Japan International Cooperations Agency/JICA, Juni2010)

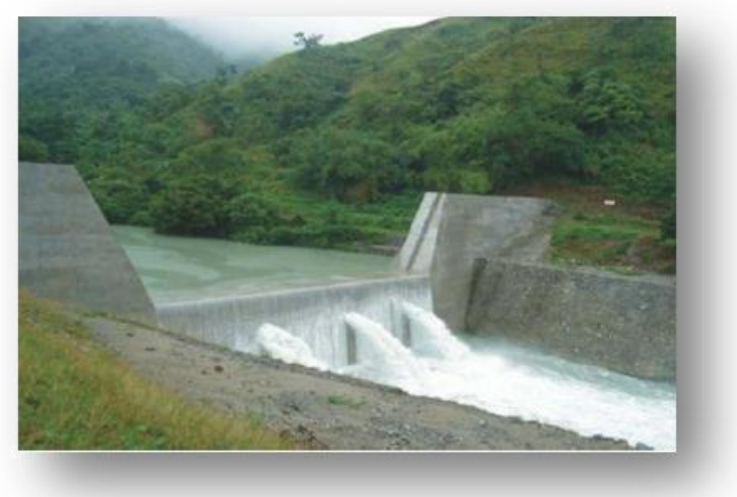

Gambar 3.Tipe Gravitasi Sabo dam sumber : Technical standards and guidelines for planning and design of sbao structures, JICA,Juni 2010

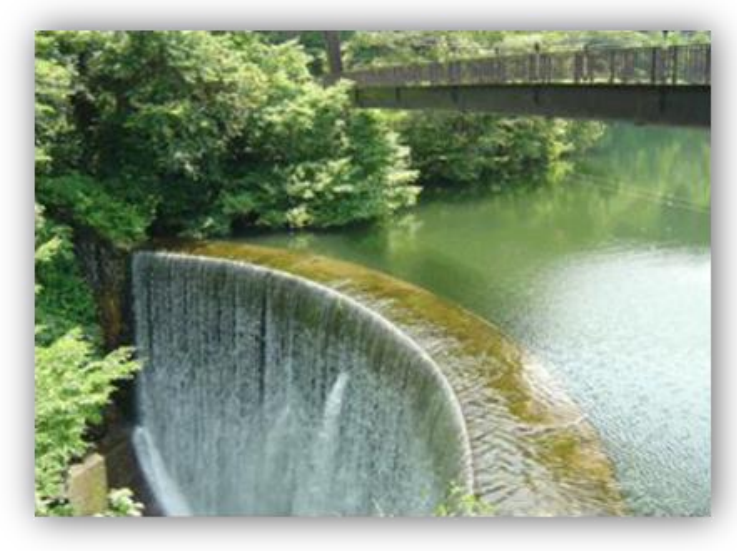

Gambar 4. Tipe Lengkung Sabo Dam sumber : Technical standards and guidelines for planning and design of sbao structures, JICA,Juni 2010 


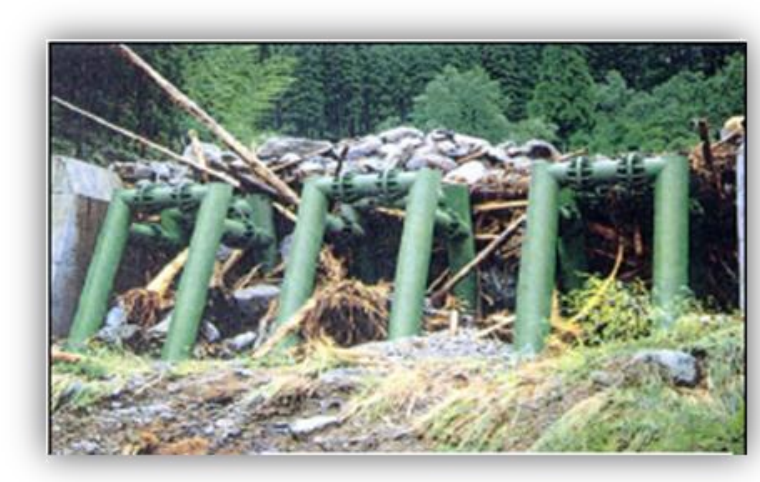

Gambar 5.Tipe Slit Sabo Dam

sumber : Technical standards and guidelines for planning and design of sbao structures, JICA,Juni 2010

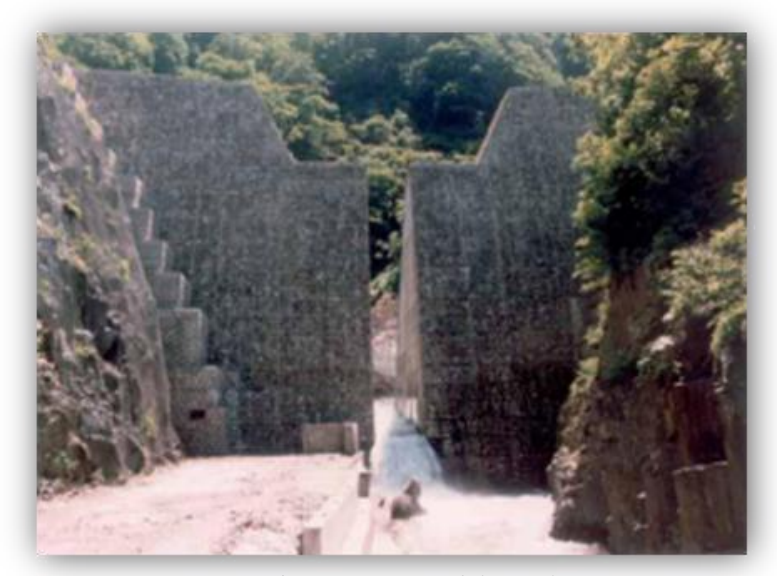

Gambar 6.Tipe Permeable Sabo Dam

sumber : Technical standards and guidelines for planning and design of sbao structures, JICA,Juni 2010

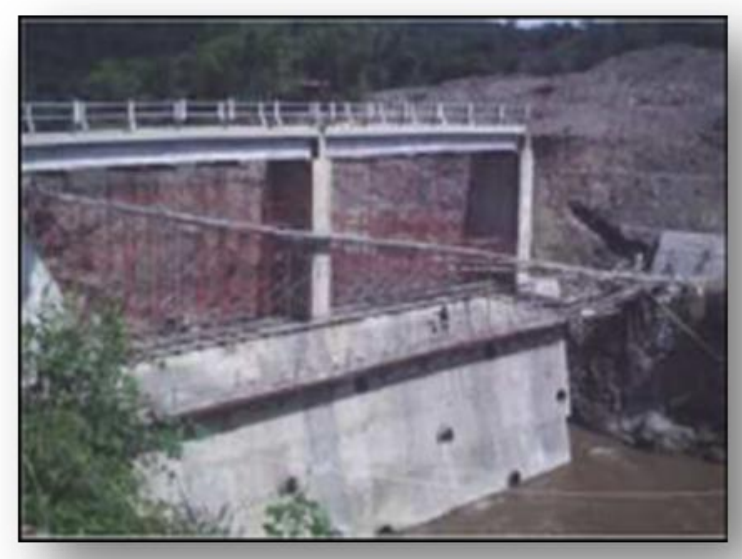

Gambar 7.Tipe Permeable Sabo Dam Sumber: UKL UPL Sabo Dam Cibatu

\section{Klasifikasi Pembangkit dan Perencanaan Pembangkit \\ Klasifikasi pembangkit listrik dapat ditentukan dari beberapa faktor (Penche,2004:3) yakni: \\ 1. Berdasarkan tinggi jatuh (head)}

- Rendah $(<50 \mathrm{~m})$

- Menegah (antara $50 \mathrm{~m}$ dan $250 \mathrm{~m}$ )

- Tinggi (> $250 \mathrm{~m})$

2. Berdasarkan tipe eksploitasi dan tampungan air

- Dengan regulasi aliran air (tipe waduk)

- Tanpa regulasi aliran air (tipe run off river)

3. Berdasarkan sistem pembawa air

- Sistem bertekanan (pipa tekan)

- Sirkuit campuran (pipa tekan dan saluran)

4. Berdasarkan penempatan rumah pembangkit

- Rumah pembangkit pada bendungan

- Rumah pembangkit pada skema pengalihan

5. Berdasarkan metode konversi energi

- Pemakaian turbin

- Pemompaan dan pemakaian turbin terbalik

6. Berdasarkan tipe turbin

- Impulse

- Reaksi

- Reversible

7. Berdasarkan kapasitas terpasang

- Mikro $(<100 \mathrm{~kW})$

- Mini (antara $100 \mathrm{~kW}$ dan $500 \mathrm{Kw}$ )

- Kecil (antara $500 \mathrm{~kW}$ dan $10 \mathrm{MW}$ )

8. Berdasarkan debit desain tiap turbin

- $\operatorname{Mikro}(\mathrm{Q}<0,4 \mathrm{~m} 3 /$ berikut:

Konsep dasar Persamaan konversi Daya sebagai

\section{Daya yang masuk = Daya yang Keluar + Kehilangan (loss) atau}

Daya yang keluar = Daya yang Masuk+Effesiensi Konversi

Daya kotor adalah tinggi terjun kotor (Hgross) yang dikalikan dengan debit air (Q) dan juga dikalikan dengan sebuah faktor gaya gravitasi $(\mathrm{g}=9.8)$, sehingga persamaan dasar dari pembangkit listrik adalah :

Pnett $=\mathrm{g} \times$ Hgross $\times \mathrm{Q} \times$ itot

dimana head dalam meter, dan debit air dalam meter kubik per detik, dan $\eta$ tot ( effisiensi total ) dalam persen dan terbagi sebagai berikut :

$\eta$ tot $=\eta$ konstruksi sipil $\times \eta$ penstock $\times \eta$ turbin $\times \eta$ generator $\times \eta$ sistem kontrol $\times \eta$ jaringan $\times \eta$ trafo.

Di mana :

$\eta$ konstruksi sipil $\quad: 1.0$ - (panjang saluran $\times 0.002$ $0.005) /$ Hgross

$\eta$ penstock $\quad: 0.90-0.95$ (tergantung pada panjangnya)

$\eta$ turbin

$\eta$ generator

$\eta$ sistem kontrol : $0.70-0.85$ (tergantung pada tipe turbin) : 0.80 - 0.95 (tergantung pada kapasistas generator) $: 0.97$ 
$\eta$ jaringan

: 0.90- 0.98 (tergantung pada panjang jaringan)

$\eta$ trafo : 0,98

$\eta$ konstruksi sipil dan $\eta$ penstock adalah yang biasa diperhitungkan sebagai 'Head Loss (Hloss) atau kehilangan ketinggian'. Dalam kasus ini, persamaan diatas dirubah ke persamaan berikut.

$\mathrm{P}$ nett $=\mathrm{g} \times($ Hgross - Hloss $) \times \mathrm{Q} \times(\eta$ tot $-\eta$ konstruksi sipil - ๆpenstock $).(\mathrm{kW})$......

Survey teknis untuk disain-disain berikut harus dilakukan setelah identifikasi dari rute jalur air. Sebuah pemahaman yang memadai tentang topografi lokal adalah penting dalam perencanaan pembangkit listrik tenaga air skala kecil terutama pada struktur sipil utama yang memiliki struktur terbuka. (Arifin dkk 2007)

\section{Tata Letak dan Elemen Proyek}

Tata letak dan elemen proyek disini dimaksudkan untuk pemilihan lokasi yang tepat dan paling ideal untuk penempatan elemen-elemen infrastruktur PLTM/H. Untuk selanjutnya harus dilakukan survey topografi detil dan survey geologi lokal di lokasi studi, untuk menetapkan lokasi definitif yang memenuhi persyaratan baik segi hidrologi maupun segi geologi permukaan.

Pada Lokasi Sabo dam Sungai Cimanuk sangat memenuhi standar kriteria kelayakan suatu potensi PLTM/H, dimana kondisi Sabo Dam Cibatu memiliki kondisi alami hidrologi sbb (Pedoman Studi kelayakan Hidrologi, Buku 2A,IMIDAP, Dirjen Listrik dan pemanfaatan energi, Dep. ESDM,2009):

a. Aliran Sungai (on stream)mencukupi debit desain turbin

b. Ketersediaan aliran air sungai sepanjang tahun (musim kering/hujan) dimana 3-4 bulan kering dalam 1 tahun

Kondisi Topografi di hulu Sabo Dam Cibatu terlihat datar cenderung landai dan meandering/berkelok, dengan sisi tebing kanan (arah aliran) cenderung tebing tegak dan tebing kiri cenderung landai.

Berdasarkan kajian dalam Pekerjaan Survey Investigasi dan Desain Sabo Dam Cibatu (2005), lokasi rencana sabo dam Cibatu dibedakan menjadi 3 (tiga) satuan batuan dasar, dari yang termuda sampai yang tertua yaitu untuk batuan dasar sungai berupa endapan terrace deposit yang berasal dari pengendapan hasil sedimentasi air sungai dengan material berupa pasir lepas, gravel, boulder.

Pada bukit kanan dan kiri sabo dam, di bagian atasnya terdapat lapisan top soil dengan ketebalan antara $1,0 \mathrm{~m}$ sampai $1,50 \mathrm{~m}$ yang berupa material lempung dan lempung pasiran, lembek dan tercampur akar tanaman.

Batuan dasar di lokasi sabo dam ini adalah batuan breksi yang umumnya bersifat keras dan kompak, serta terdapat fragmen batuan andesit.
Daya dukung batuan sangat tinggi dengan hasil $\mathbf{N}$ SPT > 50. Hasil test permeability menunjukkan batuan breksi yang masif dengan nilai koefisien permeabilitas (K) antara 10-4 sampai dengan 10-5 cm/det. Batuan ini dijumpai pada kedalaman 1,0 - 30 m di bawah permukaan tanah. Di antara batuan breksi tersebut terdapat batuan claystone yang bersifat lenses, dengan ketebalan maksimum hingga $6 \mathrm{~m}$. Di kedalaman antara 15 - 20 meter terdapat sisipan tuffaceous siltstone dengan ketebalan antara 1,0-3,0 m.

Batuan yang palingtua yang tersingkap di daerah rencana sabo dam adalah batuan lava andesit, berwarna abu - abu telah mengalami pelapukan ringan hingga fresh.

Berdasarkan Peta Hidrogeologi Indonesia, Direktorat Geologi Tata Lingkungan (Soetrisno S, 1985) Skala $1: 250.000$ terlihat bahwa di lokasi kegiatan merupakan endapan vulkanik tak teruraikan, campuran rempah gunung api lepas dan pada kelulusan rendah sampai sedang.

Alternatif pemilihan kiri intake dengan resiko paling kecil dengan pertimbangan antara lain:

1. Arah aliran tikungan dalam untuk menghindari hidraulika aliran tidak seragam

2. Pola aliran sungai, kecepatan dan arahnya pada waktu debit banjir sedang

3. Tinggi terjun yang cukup memadai

4. Lokasi lahan yang tersedia cukup luas baik untuk konstruksi maupun alternatif alternatip penempatan bangunan sipil

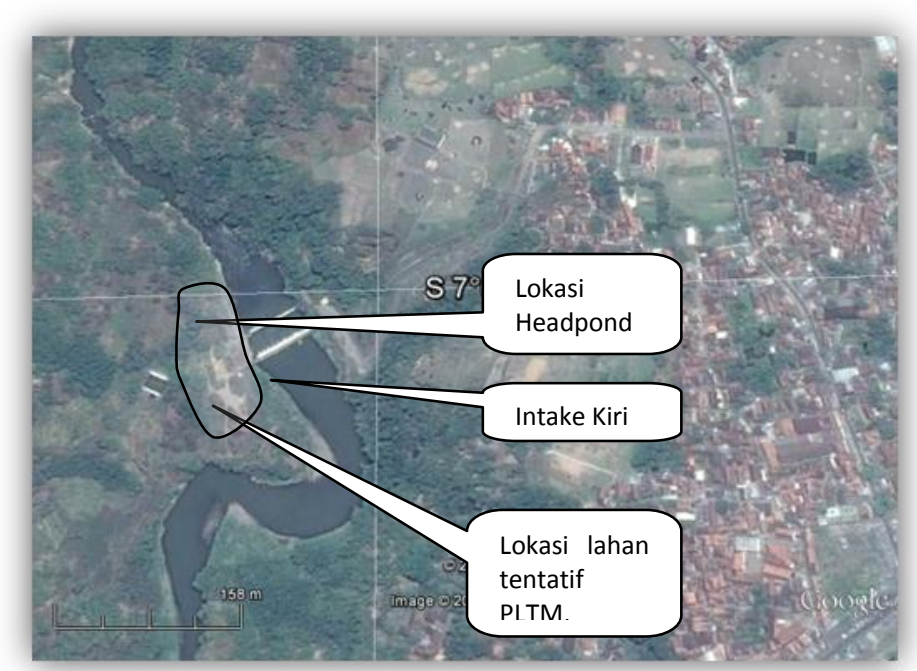

Gambar 8. Rencana tentatif lokasi PLTM Sumber: Google Earth 2015

\section{Debit Andalan}

Salah satu parameter perhitungan dalam kegiatan ini adalah topografi (kelandaian dan tinggi terjun) serta Kondisi kecukupan Debit air dalam hal ini adalah debit andalan.

Debit andalan didefinisikan sebagai debit yang tersedia guna keperluan tertentu misalnya untuk keperluan irigasi, PLTA, air baku dan lain-lain 
sepanjang tahun, dengan resiko kegagalan yang telah diperhitungkan (C.D. Soemarto,1986: 214).

Berdasarkan perhitungan pada pekerjaan SID Sabo Dam Cibatu diperoleh luas catchment area atau DPS dari rencana sabo dam Cibatu seluas $712 \mathrm{~km} 2$ serta panjang Sungai Cimanuk dari hulu sampai dengan lokasi sabo dam Cibatu adalah $44 \mathrm{~km}$.(UKL/UPL Sabo Dam Cibatu 2009)

Menurut Suyono, debit andalan terbagi atas (Suyono, 1999:204):

- Debit air musim kering: debit yang dilampaui oleh debit sebanyak 355 hari dalam setahun (97\%)

- Debit air rendah: debit yang dilampaui oleh debit sebanyak 275 hari dalam setahun $(75 \%)$

- Debit air normal: debit yang dilampaui oleh debit sebanyak 185 hari dalam setahun $(50,6 \%)$

- Debit air cukup cukup: debit yang dilampaui oleh debit sebanyak 95 hari dalam setahun (26\%).

Komponen-komponen PLTM/Hyang direncanakan diantaranya adalah:

1. Bangunan Pengambilan

2. Bangunan Pembawa

3. Bangunan Pengendap

4. Pipa Pesat dan Support

5. Bangunana Pembuang

PLTM/H Cibatu ini dirancang untuk memanfaatkan aliran sungai Cimanuk pada Sabo Dam cibatu.

Konsep PLTM/H Cibatu dirancang sebagai minihidro dengan konsep run off river. Dengan konsep ini maka penggunaan air untuk keperluan pembangkit tidak menggangu aliran maupun fungsi sungai.

Aliran air sekedar disadap untuk menggerakkan turbin dan dikembalikan lagi ke aliran sungai Cibatu (di belakang apron /kolam olak). Sabo dam dan intake berfungsi untuk mengarahkan aliran air ke bak penenang (forebay).

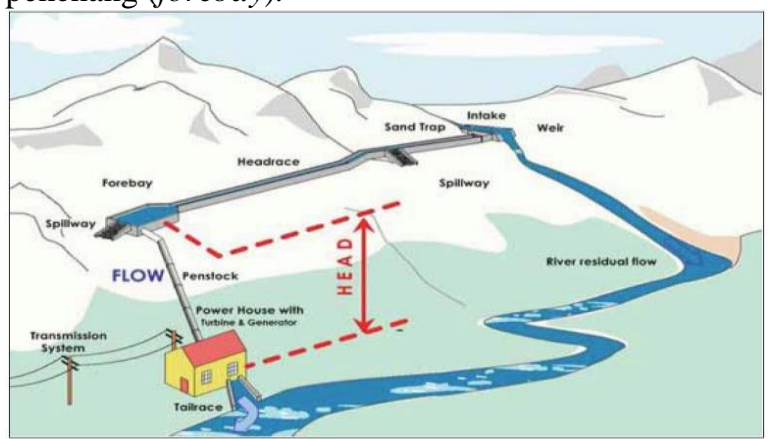

Gambar 9.Skema PLTM run of river plant

\section{Perencanaan dasar PLTM}

\section{a. Bangunan pengambilan (Intake)}

Bangunan ini biasanya dilengkapi dengan pintu dan saringan (trashrack) guna menghindari masuknya sedimen.

Bangunan Pengambilan (Intake)

Untuk perencanaan pintu bilas digunakan rumus:

$$
\mathrm{Q}=\mu . \mathrm{b} . \mathrm{h} \cdot \sqrt{2} \cdot \mathrm{g} \cdot \mathrm{z} \text {. }
$$

Di mana:

$$
\begin{aligned}
& \mathrm{Q}=\text { debit rencana }\left(\mathrm{m}^{3} / \mathrm{dtk}\right) \\
& \mathrm{b}=\text { lebar pintu }(\mathrm{m}) \\
& \mathrm{h}=\text { tinggi bukaan pintu intake }(\mathrm{m}) \\
& \mathrm{g}=\text { gaya gravitasi }\left(9,8 \mathrm{~m} / \mathrm{dtk}^{2}\right) \\
& \mathrm{Z}=\text { beda tinggi muka air di hulu dan di hilir }
\end{aligned}
$$

intake

(m)

$\mathrm{m}=$ koefisien konstruksi $(0,85-0,90)$.

\section{b. Saluran Pengarah}

Saluran pengarah direncanakan untuk mengalirkan air dari bendung menuju ke bak pengendap sedimen, sebesar debit andalan dengan perhitungan sebagai berikut:

$$
\begin{aligned}
& \mathrm{V}=1 / \mathrm{n} . \mathrm{R}^{2 / 3} \cdot \mathrm{S}^{1 / 2} \\
& \mathrm{Q}=\mathrm{V} . \mathrm{A} \ldots \ldots \ldots \ldots \ldots \ldots \ldots
\end{aligned}
$$

Di mana:

$$
\begin{array}{ll}
\mathrm{Q} & =\text { debit rencana }\left(\mathrm{m}^{3} / \mathrm{dtk}\right) \\
\mathrm{n} & =\text { koefisien kekasaran manning } \\
\mathrm{V} & =\text { kecepatan aliran }(\mathrm{m} / \mathrm{dtk}) \\
\mathrm{R} & =\text { jari-jari hidraulis }(\mathrm{m}) \\
\mathrm{S} & =\text { kemiringan dasar saluran } \\
\mathrm{A} & =\text { luas }\left(\mathrm{m}^{2}\right)
\end{array}
$$

\section{c. Bak Pengendap (Sandtrap0}

Bak pengendap merupakan bangunan yang berfungsi penangkap sedimen yang ukurannya lebih besar dari ukuran minimum yang dapat merusak turbin.

$\mathrm{LB}=\mathrm{Q} / \mathrm{w}$

di mana:

$\mathrm{H} \quad=$ kedalaman aliran saluran, $\mathrm{m}$

$\mathrm{W} \quad=$ kecepatan endap partikel sedimen,

$\mathrm{m} / \mathrm{dt}$

$\mathrm{L}=$ panjang kantong lumpur, $\mathrm{m}$

\begin{tabular}{|c|c|c|c|}
\hline \multicolumn{4}{|c|}{ Roughness, Design Velocity and Side Slope } \\
\hline Material & |Manning's n & Design welocity $(\mathrm{m} / \mathrm{s})$ & Side Slope, m (H/N) \\
\hline Wet masoniry 1 & 0.017 & 1.00 & \begin{tabular}{|l|l|}
0.67 \\
\end{tabular} \\
\hline Wet masonry 2 & 0.017 & 1.00 & 0.00 \\
\hline Wet masonry 3 & 0.017 & 1.25 & 0.00 \\
\hline Concrete & 0.014 & 2.00 & 0.00 \\
\hline Syphon & 0.012 & 2.50 & 0.00 \\
\hline Earth $Q ? 5 \mathrm{~m}^{3} / \mathrm{s}$ & 0.025 & 0.70 & 1.50 \\
\hline Others & 0.014 & 0.30 & 0.00 \\
\hline
\end{tabular}

Q = debit saluran, $\mathrm{m}^{3} / \mathrm{dt}$

B = lebar kantong lumpur, $\mathrm{m}$

Dimensi bak pengendap sebaiknya juga sesuai dengan kaidah bahwa $\mathrm{L} / \mathrm{B}>8$, untuk mencegah agar aliran tidak "meander" di dalam kantong.

\section{d. Saluran Pembawa(waterway)}

Saluran yang akan membawa debit air sesuai debit desain yang telah ditetapkan, Tipe saluran ini bisa berupa open chanel maupun close conduit tergantung area yang akan dilewati ataupun tersedia. Koefesien kekasaran saluran dan free board yang ditetapkan adalah sebagai berikut:

Tabel 1. Koefesien kekasaran 
Tabel 2. Tinggi jagaan Freeboard

\begin{tabular}{l|l|l} 
Discharge $\left(\mathrm{m}^{3} / \mathrm{s}\right)$ & Earthen channel $(\mathrm{m})$ & Lin \\
\hline 0.5 & 0.40 & 0.20 \\
1.5 & 0.50 & 0.20 \\
5.0 & 0.60 & 0.25 \\
10.0 & 0.75 & 0.30 \\
15.0 & 0.85 & 0.40 \\
$>15.0$ & 1.00 & 0.50
\end{tabular}

Sumber: ven te chow\& sumber lainnya

Rumus yang digunakan adalah sebagai berikut

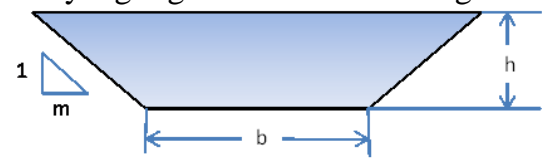

$\mathrm{Q}=\mathrm{V} \cdot \mathrm{A}\left(\mathrm{m}^{3} / \mathrm{det}\right)$

Dimana

$$
\begin{aligned}
& A=(b+m h) h=\text { Luas Basah } \\
& V=1 / n \cdot R^{2 / 3} \cdot S^{1 / 2}=\text { Kecepatan Air di sal. } \\
& R=A / P \quad=\text { Jari Jari Hidrolis.......(8) } \\
& P=b+2 h \sqrt{ }\left(1+\mathrm{m}^{2}\right)=\text { Keliling Penampang }
\end{aligned}
$$$$
\text { Basah. }
$$$$
\mathrm{I}=\mathrm{v}^{2} \mathrm{n}^{2} / \mathrm{R}^{4 / 3}=\text { long. Slope. }
$$

\section{e. Pipa pesat (Penstock)}

Dimensi penstock dengan ketentuan sebagai berikut:

- Penentuan diameter

Berdasarkan dari persamaan Sarkaria adalah (Juwono, 1992: 26)

$$
\begin{array}{ll}
\mathrm{H}<50 \mathrm{~m} & : \mathrm{D}=0.794 \times \mathrm{Qp}^{0.404} \\
\mathrm{H}=50-100 \mathrm{~m} & : \mathrm{D}=0.785 \times \mathrm{Qp}^{0.400} \\
\quad \text { Atau } &
\end{array}
$$

Berdasarkan persamaan Gordon dan Penman (1979) $\mathrm{Dp}=0.72 \mathrm{Q}_{\mathrm{P}}^{0.5}$.

$$
\begin{aligned}
& \text { Dimana } \\
& \mathrm{D}=\text { diameter penstock, } \mathrm{m} \\
& \mathrm{H} \quad=\text { tinggi jatuh pada turbin, } \mathrm{m} \\
& \mathrm{Qp} \quad=\text { debit pada penstock, } \mathrm{m}^{3} / \mathrm{det}
\end{aligned}
$$

\begin{tabular}{|c|c|c|c|}
\hline Reach & BA1 & Unit & Remarks \\
\hline \multicolumn{4}{|l|}{ 1. Basic } \\
\hline $\begin{array}{l}\text { Design static head: } \\
\text { Design dynamic heat: }\end{array}$ & $\begin{array}{l}11.88 \\
10.20\end{array}$ & $\begin{array}{l}\mathbf{m} \\
\mathbf{m}\end{array}$ & \\
\hline \multirow{2}{*}{\multicolumn{4}{|c|}{ Design distarge:- }} \\
\hline \multirow{2}{*}{\multicolumn{4}{|c|}{$D_{n=0}=720^{05}$ (G) }} \\
\hline & & & \\
\hline v. & 12.94 & $\mathbf{m} / \mathbf{s}$ & $\mathrm{Dp}=0.794 \mathrm{Q}^{0.404}(\mathrm{H}$ iwuno, $1992 \mathrm{20})$ \\
\hline \multicolumn{4}{|l|}{ 3. Thickness } \\
\hline 3a. Normal & 11620 & lipa & \multirow{4}{*}{$\begin{array}{l}\text { Wediled pipe } \\
\text { IIS G3106 SM490 of }=535000 \mathrm{kPa}, \mathrm{FS}=3 \\
t=1000 \mathrm{pD} / \mathrm{fef}\end{array}$} \\
\hline & & & \\
\hline Allowatle stress, fi & 178333 & $\mathbf{l} \mathbf{P a}$ & \\
\hline Calculatied thichess, $t$ & 039 & $\operatorname{mm}$ & \\
\hline \multicolumn{4}{|l|}{ 3b. Temporary } \\
\hline Dymmic head, p: & 99.76 & lipa & \multirow{4}{*}{$\begin{array}{l}\text { Welied pipe } \\
\text { IIS G3106 SM490 } \mathrm{f}_{\mathrm{u}}=535000 \mathrm{kPa}, \mathrm{FS}=15 \\
\mathrm{t}=1000 \mathrm{pD} / 2 \mathrm{ef}\end{array}$} \\
\hline e: & 09 & & \\
\hline Allowalte stress, ff & 356607 & $\mathbf{l P a}$ & \\
\hline Calcriatited thictmess, $t$ & 0.17 & mm & \\
\hline \multicolumn{4}{|l|}{ 3c. Minimum thickness } \\
\hline Cortusion allowance, ty & 200 & $\mathbf{m m}$ & \multirow{7}{*}{ 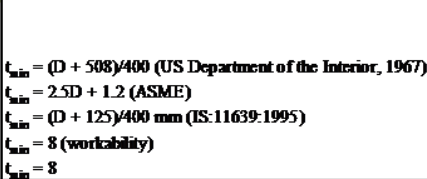 } \\
\hline Required thindmess, timi & 239 & $\operatorname{mm}$ & \\
\hline Minimum thickness, thier & 127 & $\mathrm{~mm}$ & \\
\hline & 3.88 & $\mathrm{~mm}$ & \\
\hline & 032 & $\mathbf{m m}$ & \\
\hline & 8.000 & $\mathrm{~mm}$ & \\
\hline Adopted thidmess, $t$ & 8.000 & $\operatorname{mm}$ & \\
\hline \multicolumn{3}{|l|}{ 4. Headloss } & \multirow{7}{*}{ 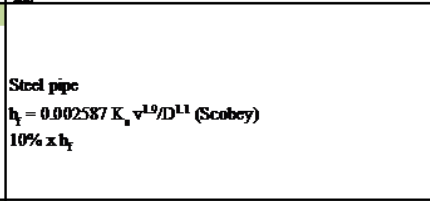 } \\
\hline & 14.00 & $\mathbf{m}$ & \\
\hline Cummuhtive L:- & 14.60 & & \\
\hline & 0.42 & & \\
\hline & 1.83 & & \\
\hline Minor losses: & 0.18 & $\mathbf{m}$ & \\
\hline he: & $\begin{array}{l}201 \\
201\end{array}$ & & \\
\hline \multicolumn{4}{|l|}{\begin{tabular}{|l|} 
5. Support distance \\
\end{tabular}} \\
\hline Pipe weight ind waler, $P$ - & 1111 & $\mathrm{~kg} / \mathrm{m}$ & \multirow[b]{2}{*}{$L=182.61\left((D+0.0147)^{4}-D^{t} y P\right)^{13}$} \\
\hline Maximam Support distrance, $\mathrm{L}$ : & 739 & $m$ & \\
\hline \multicolumn{3}{|l|}{ 6. Time constant } & \multirow[b]{2}{*}{$\mathbf{T}_{\mathrm{w}}=\mathrm{L} /\left(\mathrm{A}_{\mathrm{q}}\right) \times \mathrm{Q} / \mathrm{H}$} \\
\hline $\begin{array}{l}\text { Sectional arca, } A_{\bar{c}} \\
\text { Time constant, } T_{w}=\end{array}$ & $\begin{array}{r}0.980 \\
156\end{array}$ & & \\
\hline
\end{tabular}

- Kecepatan yang terjadi (Varshney,197:404)

$\mathrm{V}=0.125 \sqrt{ } 2 \mathrm{gH}$

$\mathrm{V}=$ Kecepatan yang diijinkan penstock $\mathrm{m} / \mathrm{det}$

- Ketebalan Pipa

$$
\begin{aligned}
& \mathrm{t}_{\min }=(\mathrm{D}+508) / 400 \text { (US Department of the Interior, } \\
& 1967) \\
& \mathrm{t}_{\min }=2.5 \mathrm{D}+1.2(\text { ASME) } \\
& \mathrm{t}_{\min }=(\mathrm{D}+125) / 400 \mathrm{~mm} \text { (IS:11639:1995)...........(15) } \\
& \text { Dimana } \mathrm{D}=\text { Diameter Pipa Penstock } \\
& \mathrm{t}_{\min }=\text { ketebalan pipa minimum }
\end{aligned}
$$

Terdapat beberapa formula untuk perhitungan tersebut diatas, maka kami sarikan dalam bentuk tabel
Tabel 3. Perhitungan Penstock (ilustrasi)

Sumber :hasil perhitungan

Gedung Pembangkit Beserta Peralatan Elektro Mekaniknya

Dimensi panjang, lebar dan tinggi power house sangat tergantung pada dimensi runner, spiral casing dan draft tube serta jumlah dari turbin. Sedangkan tinggi power house tergantung dari elevasi as turbin, dimensi draft tube dan tinggi generatornya.

\section{f. Saluran Air Buritan (Tailrace)}

Adalah saluran terbuka yang dilalui oleh air yang keluar dari draft tube dan berakhir sampai ke sungai. Tile Water Level (TWL) adalah elevasi muka air dihilir, dimana tinggi dari TWL tergantung dari debit air yang keluar dari turbin, jenis penampang serta dimensi penampang saluran pembuang.

\section{g. Kehilangan Tinggi (Head Loss)}

Kehilangan tinggi tekan digunakan untuk endapatkan tinggi efektif pasokan air yang diperlukan untuk perencanaan energi listrik. Kehilangan tinggi tekan (head loss) diperhitungkan sepanjang saluran pembawa (waterway). Persamaan umum kehilangan tinggi tekan adalah sebagai berikut (Linsley, 2000: 307)

$$
\mathrm{h}_{\mathrm{L}}=\mathrm{k} \cdot \mathrm{v}^{2} / 2 \mathrm{~g} \text {. }
$$

dimana:

$$
\begin{aligned}
& \mathrm{h}_{\mathrm{L}}=\text { kehilangan tinggi, } \mathrm{m} \\
& \mathrm{k}=\text { koefisien kehilangan tinggi } \\
& \mathrm{v}=\text { kecepatan aliran, } \mathrm{m} / \mathrm{det} \\
& \mathrm{g}=\text { percepatan gravitasi, } \mathrm{m} / \mathrm{det}^{2}
\end{aligned}
$$




\section{h. Tinggi Jatuh Effektif (Head Effective)}

Adalah selisih antara muka air Normal di Headpond (El. MAN) dengan elevasi tail water level (El. TWL) dikurangi dengan total kehilangan tinggi tekan (Varshney,1977: 562) Persamaan tinggi jatuh efektif adalah:

$$
\mathrm{H}_{\mathrm{eff}}=\mathrm{El} . \mathrm{MAN}-\mathrm{El} . \mathrm{TWL}-\mathrm{h}_{\mathrm{L}}
$$

Dimana,

$$
\begin{array}{ll}
\text { Heff } & =\text { tinggi jatuh effektif, } \mathrm{m} \\
\text { El. MAN } & =\text { elevasi muka air bak penenang, } \mathrm{m} \\
\text { El. TWL } & =\text { elevasi tail water level, } \mathrm{m} \\
\mathrm{hL} & =\text { total kehilangan tinggi tekan, } \mathrm{m}
\end{array}
$$

Analisa Kelayakan

Dilakukan untuk mengetahui kelayakan suatu proyek dari segi ekonomi. Dalam melakukan analisa kelayakan dibutuhkan komponen utama:

a. komponen biaya (cost) yaitu berupa biaya konstruksi, biaya tak terduga (contigencies), biaya engineering, dan biaya O\& $\mathrm{P}$ tahunan.

b. komponen manfaat (benefit), didasarkan pada tenaga listrik yang dihasilkan tiap tahun dan tarif dasar listrik yang berlaku.

\section{Parameter Kelayakan Ekonomi}

Indikator yang sering dipakai dalam analisa ekonomi,yaitu:

a. Perbandingan manfaat dan biaya (BCR)

$$
\mathrm{BCR}=\frac{\text { Nilai sekarang (benefit) }}{\text { Nilai sekarang (biaya) }}=\frac{p V b}{\text { pVe }}
$$

b. Selisih manfaat dan biaya (Net Present Value) $\mathrm{NPV}=\mathrm{PV}$ Benefit - PV Cost

c. Tingkat pengembalian internal (Internal Rate of Return)

$$
\text { IRR }=\frac{\text { NPV }}{\text { Nilai sekarang (biaya) }}
$$

\section{Analisa Sensitivitas}

Keadaan yang ditinjau dalam analisa sesitivitas adalah sebagai berikut:

a. Kondisi Normal

b. Terjadi kenaikan $10 \%-20 \%$ pada biaya proyek yang diperkirakan.

c. Terjadi penurunan $10 \%-20 \%$ pada nilai manfaat yang diperkirakan.

\section{Metodologi Penelitian}

\section{Lokasi Studi}

Berada di Desa Keresek, Kecamatan Cibatu, dan desa Leuwigoong, Kecamatan Leuwigoong, Kabupaten Garut, Provinsi Jawa Barat

\section{Tahapan Penyelesaian Studi Potensi}

\section{Penetapan debit desain}

Dilakukan dengan pendekatan rumus debit di atas mercu sabo dam

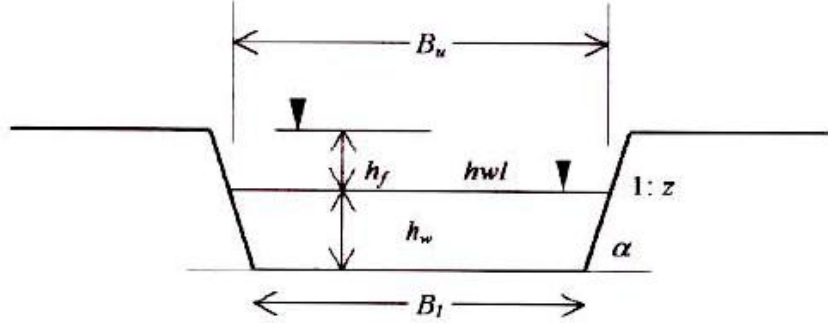

Jika $\mathrm{z}=0.5$, maka $\mathrm{h}_{\mathrm{w}}$ dihitung dengan rumus $\mathrm{Q}=\left(1.77 . \mathrm{B}+0.71 . \mathrm{h}_{\mathrm{w}}\right) \mathrm{h}_{\mathrm{w}}{ }^{3 / 2}$....

Jika $\mathrm{z}=1.0$, maka $\mathrm{h}_{\mathrm{w}}$ dihitung dengan rumus $\mathrm{Q}=\left(1.77 . \mathrm{B}+1.42 . \mathrm{h}_{\mathrm{w}}\right) \mathrm{h}_{\mathrm{w}}{ }^{3 / 2}$.....

Dimana

$\mathrm{Qd}=$ debit aliran debris $\left(\mathrm{m}^{3} / \mathrm{det}\right)$

$\mathrm{h}_{\mathrm{w}}=$ Kedalaman Pelimpah $(\mathrm{m})$

$\mathrm{B}_{1}=$ Lebar dasar Pelimpah (m)

2. Perencanaan dasar bangunan Sipil

- Penentuan alternatif lokasi yaitu alternatif 1 di sebelah kiri sabo dam dan alternatif 2 di sebelah kanan sabo dam Cibatu

- Perencanaan dasar pipa pesat yaitu diameter dan tebal pipa pesat

- Analisis tinggi jatuh efektif $\left(\mathrm{H}_{\mathrm{eff}}\right)$, dimana faktor kehilangan sudah diperhitungkan

- Penentuan jenis turbin dan Generator

- Analisa daya dan energi yang mampu di bangkitkan

\section{Hasil dan Pembahasan}

a. Penetapan Debit rencana yang akan dimanfaatkan untuk debit pembangkitan adalah sebesar 40 persen dari debit yang melimpas di mercu Sabo Dam Cibatu. Debit desain untuk pembangkitan adalah sebesar $\mathrm{Q}=\left(1.77 . \mathrm{B}+0.71 . \mathrm{h}_{\mathrm{w}}\right) \mathrm{h}_{\mathrm{w}}{ }^{3 / 2}=\mathbf{1 7 . 7 8} \mathrm{m}^{3} / \mathrm{det}$ Dan $65 \%$.Q $=\mathbf{1 1 . 5 5 5} \mathrm{m}^{3} /$ det

\section{Data teknis Sabo Dam Cibatu (UKL UPL sabo dam} cibatu,2009)

Main Dam:

- Tinggi main dam : 13,00 m

- Elevasi puncak mercu : EL.556,00 m

- Lebar mercu : 2,50 m

- Kemiringan hilir : 0,20

- Kemiringan hulu : 0,50

- Lebar dasar pondasi : 17,00 m

Pelimpah:

- Lebar dasar : 50,00 m

- Elevasi dasar pelimpah : EL.556,00 m

- Kemiringan dinding kiri \& kanan : 0,50

- Tinggi pelimpah \& jagaan : 5,80 m

- Apron:

- Panjang lantai apron : 21,05 m

- Tebal Lantai Apron : 2,00 m

- Elevasi permukaan lantai : EL. 545,00 m

- Elevasi dasar lantai pondasi : EL. 543,00 m

Sub Dam:

- Tinggi : 2,50 m 


\begin{tabular}{|c|c|c|c|c|c|c|c|}
\hline \multirow[t]{2}{*}{ No. } & \multirow[t]{2}{*}{ Uraian } & \multirow{2}{*}{$\begin{array}{c}\begin{array}{c}\text { Debit } \\
Q\end{array} \\
\mathrm{~m}^{3} / \mathrm{det} \\
\end{array}$} & \multirow{2}{*}{$\begin{array}{c}\begin{array}{c}\text { Tinggi Effektif } \\
\mathrm{H} \text { eff }\end{array} \\
\mathrm{m} \\
\end{array}$} & \multicolumn{2}{|c|}{$\begin{array}{l}\text { Kapasitas } \\
\text { Terpasang }\end{array}$} & \multirow{2}{*}{$\begin{array}{c}\text { Energi } \\
\text { Tahunan } \\
\mathrm{AE}(\mathrm{GWh})\end{array}$} & \multirow{2}{*}{$\begin{array}{c}\begin{array}{c}\text { Faktor } \\
\text { Kapasitas }\end{array} \\
\text { CF }(\%)\end{array}$} \\
\hline & & & & $\mathrm{P}(\mathrm{KW})$ & MW & & \\
\hline & 1 & 2 & 3 & 4 & 5 & 6 & \\
\hline 1 & Bulan Basah selama 6 bulan & 11.555 & 11.88 & 1279.41 & 1.279 & 5.619 & \\
\hline 2 & Bulan Peralihan selama 2 bulan & 7.510 & 11.88 & 831.61 & 0.832 & 1.217 & 57.6825079 \\
\hline 3 & Bulan Kering selama 4 bulan & 4.044 & 11.88 & 413.53 & 0.414 & 1.588 & \\
\hline \multicolumn{4}{|c|}{ Sub-Total Energi tahunan } & & & 8.425 & \\
\hline 4 & Pemeliharaan selama 15 hari & 11.555 & 11.88 & 1279.41 & 1.279 & 0.461 & \\
\hline & Real Total Energi tahunan terjua & & & & & 7.964 & \\
\hline
\end{tabular}

- Lebar mercu : 2,50 m

- Elevasi mercu : EL. 547,50 m

- Kemiringan hilir : 0,20

- Kemiringan hulu : 0,50

- Lebar dasar : 8,44 m

- Elevasi dasar : EL. 539,55 m

Proteksi Dasar Sungai di Hilir Sub Dam

- Panjang lantai beton : 11,50 m

- Tebal lantai : 1,00 m

- Elevasi permukan lantai : EL. 541,55 m

- End Sill

- Lebar : 1,00 m

- Dalam : 3,00 m

- Elevasi dasar pondasi : EL. 539,55 m

- Elevasi puncak : EL. 542,55 m

Tabel 4. Simulasi Tinggi Air dan Debit diatas mercu

\begin{tabular}{|c|c|c|c|c|}
\hline \multirow{2}{*}{ No } & $\mathrm{h}_{\mathrm{w}}$ & $\mathrm{B}$ & Debit Di Mercu & Elev. MA. \\
\cline { 2 - 5 } & $(\mathrm{m})$ & $(\mathrm{m})$ & $\left(\mathrm{m}^{3} /\right.$ det $)$ & Diatas Mercu $(\mathrm{m})$ \\
\hline 1 & 0.3 & 61 & 17.78 & 556.3 \\
2 & 0.4 & 61 & 27.39 & 556.4 \\
3 & 0.5 & 61 & 38.30 & 556.5 \\
4 & 0.6 & 61 & 50.38 & 556.6 \\
5 & 0.7 & 61 & 63.53 & 556.7 \\
6 & 0.8 & 61 & 77.66 & 556.8 \\
7 & 0.9 & 61 & 92.73 & 556.9 \\
8 & 1.0 & 61 & 108.68 & 557.0 \\
\hline
\end{tabular}

Sumber: Hasil Perhitungan

Kehilangan tinggi energi dari sepanjang bendung sampai kolam penenang adalah sebesar $12.2 \mathrm{~cm}$

b. Penentuan tinggi Head/Terjun effektif elev.=

$+555.71-543.71=12 \mathrm{~m}-0.122 \mathrm{~m}($ headloss $)=$ $11.88 \mathrm{~m}$.

c. Perencanaan dasar Penstock/Pipa pesat setelah dihitung seperti tabel 3 adalah 1.07 m (inner diameter) per pipa yang direncanakan 2 buah pipa pesat, dengan panjang total pipa penstock direncanakan adalah 14 meter dipasang berdampingan. Adapun besar kehilangan tinggi energi di pipa pesat sebesar $\mathbf{2 . 0 1} \mathrm{m}$.

Dengan Data $\mathrm{H}_{\text {effektif }}$ dan Debit desain yang telah dihitung maka penentuan kapasitas debit pembangkitan dapat dihitung berdasarkan formula no 1 didapatkan nilai seperti dibawah ini:

Tabel 5.Simulasi Daya Pembangkitan dan Energi Terbangkitkan Tahunan

Sumber: Hasil Perhitungan

d. Analisa Pembangkitan Energi

Produksi energi tahunan dihitung berdasarkan tenaga andalan. Tenaga andalan dihitung berdasarkan debit andalan yang tersedia untuk pembangkitan energi listrik yang berupa debit outflow dengan periode $\mathrm{n}$ harian. (arismunandar, 2005:19)

$\mathrm{E}=9,8 \times \mathrm{H} \times \mathrm{Q} \times \eta \mathrm{g} \times \eta \mathrm{t} \times 24 \times \mathrm{n} .$.

Efesiensi generator dan efesiensi turbin ditetapkan sebesar $95 \%$ dan jam operasional turbin selam 24 jam, serta maintenancei dalam 1 tahun (meliputi pembersihan, pemeliharaan rutin penggantioan greese, sikring dan lainnya diasumsikan selama 15 hari dalam 1 tahun.

Bulan basah diasumsikan selama 6 bulan dan bulan peralihan selama 2 bulan serta bulan kering dianggap 4 bulan sebagai pertimbangan dari kondisi iklim dan cuaca di lokasi studi (sumber: UKL UPL sabo dam Cibatu,2009)

e. Pemilihan tipe turbin

Mekanisme dan prosedur pemilihan jenis turbin menggunakan grafik seperti dibawah ini

Dengan debit $11.55 \mathrm{~m}^{3} /$ det dan head net $11.88 \mathrm{~m}$ maka jenis turbin yang bisa dipasang adalah jenis francis maupun kaplan berdasarkan grafik tersebut 


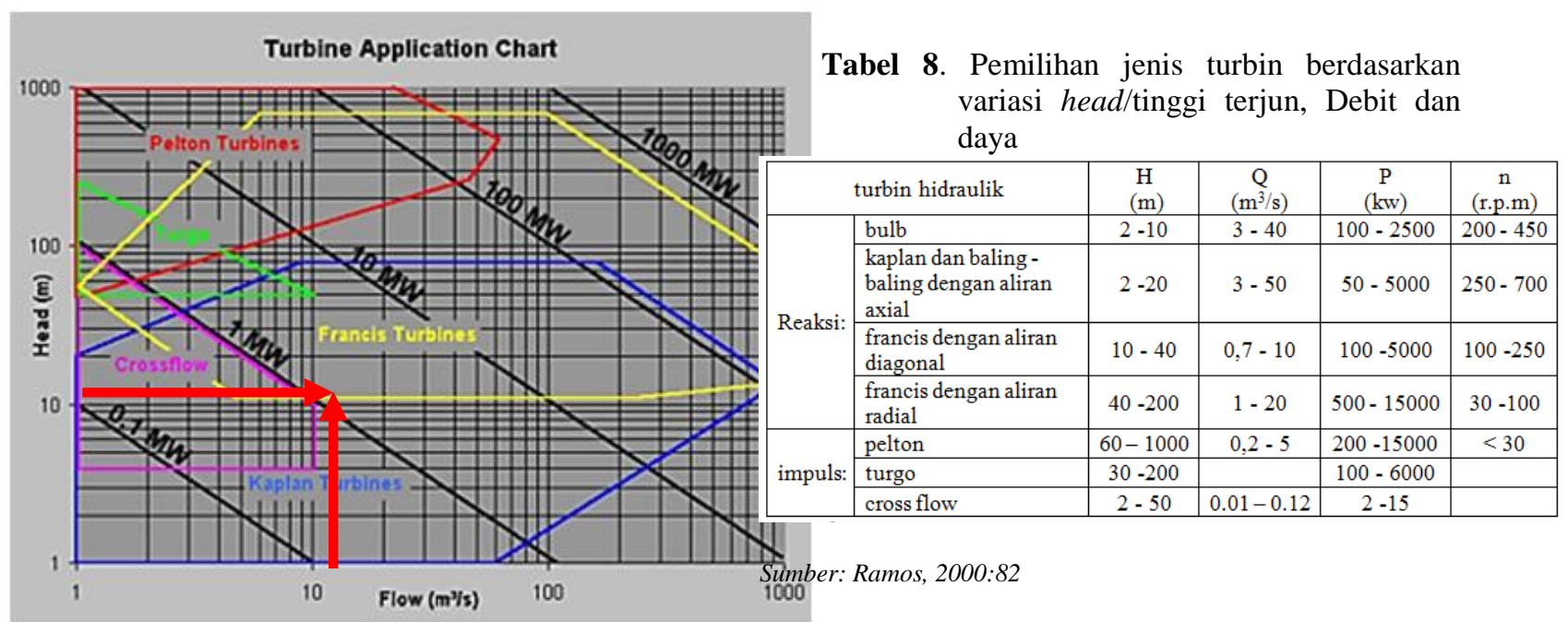

Gambar 10. Grafik Pemilihan Jenis turbin

$$
\text { Ns }=\mathbf{n} . \mathbf{P}^{0.5} / \mathbf{H}^{5 / 4}
$$

Dimana :

$\mathrm{NS}=$ kecepatan spesifik

$\mathrm{n}=$ kecepatan putaran turbin (rpm)

$=(120 * \mathrm{f}($ frekuensi gen $) / \mathrm{p}($ Jumlah pole generator)

(hydropower Engineering;CC warnick)

$\mathrm{P}=$ maksimum turbin output $(\mathrm{kW})$

$\mathrm{H}=$ head efektif $(\mathrm{m})$
Dari Beberapa Metode pemilihan jenis turbin tersebut maka jenis yang akan dipakai dalam PLTM Cibatu adalah jenis propeler atau kaplan

f. Analisa ekonomi

Berdasarkan peraturan menteri ESDM no. 12 tahun 2014 harga jual listrik yang harus dibeli PT. PLN adalah Rp. 1075/kWh. Maka nilai manfaat dari penjualan listrik adalah: harga jual $\mathrm{x}$ hasil bangkitan energi listrik $=1075 \times 7.964=$ 8.56 Milyar/tahun

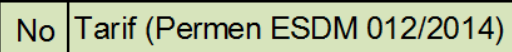 \\ 1 a. Rp 1075 x Faktor Tarif (Tahun 1-8) \\ 2 b. Rp 750 x Faktor Tarif (Tahun 9-20) \\ 3 Faktor Tarif \\ 4 Operation \& Maintenance Cost \\ 5 Other Expenses (CSR and Other)}

$\mathrm{Ns}=\left(120^{*}(50 / 18)\right) . \times 1279.41^{0.5} / 11.555^{5 / 4}=$ $395.7 \mathrm{rpm}$

Jadi Kecepatan aktual spesifik adalah 395. rpm

Tabel 6. Pemilihan jenis turbin berdasarkan Kecepatan Spesifik bisa dilihat dalam tabel berikut

\begin{tabular}{|l|l|c|}
\hline No. & \multicolumn{1}{|c|}{ Jenis Turbin } & Kecepatan Spesifik \\
\hline 1 & Turbin Pelton & $12 \leq \mathrm{Ns} \leq 25$ \\
\hline 2 & Turbin Francis & $60 \leq \mathrm{Ns} \leq 300$ \\
\hline 3 & Turbin Crossflow & $40 \leq \mathrm{Ns} \leq 200$ \\
\hline & Turbin & \\
4 & Propeller/Kaplan & $250 \leq \mathrm{Ns} \leq 1000$ \\
\hline
\end{tabular}

Tabel 7. Pemilihan jenis turbin berdasarkan variasi head/tinggi terjun

\begin{tabular}{|c|l|c|}
\hline No. & \multicolumn{1}{|c|}{ Jenis Turbin } & Variasi Head \\
\hline 1 & Kaplan dan Propeller & $2<\mathrm{H}<20$ \\
\hline 2 & Francis & $10<\mathrm{H}<350$ \\
\hline 3 & Pelton & $50<\mathrm{H}<1000$ \\
\hline 4 & Crossflow & $6<\mathrm{H}<100$ \\
\hline 5 & Turgo & $50<\mathrm{H}<250$ \\
\hline
\end{tabular}

\begin{tabular}{r|l|l|r|l|} 
& & GWh & \multicolumn{2}{|c|}{ Pendapatan } \\
\cline { 2 - 3 } $\mathbf{1 , 0 7 5}$ & IDR/kWh & 7.964 & 8.56 & Milyar/tahun \\
750 & IDR/kWh & 7.964 & 5.97 & Milyar/tahun \\
1.00 & Jawa & 7.964 & 8.56 & Milyar/tahun \\
& From Sales & 856.13 & Juta/tahun \\
$0.4 \%$ & From Sales & 34.25 & Juta/tahun \\
\hline
\end{tabular}

Tabel 9. Estimasi Pendapatan Oprasional PLTM

Aliran dana (cash flow) disusun selama 20 tahun (kontrak PPA lpower purchase agreement dengan PLN), dalam tabel cash flow masing masing parameter dihitung dalam bentuk nilai ekuivalensinya $(\mathrm{P} / \mathrm{V})$ untuk tiap parameter. Kemudian akan dianalisa kelayakan ekonominya dalam bentuk benefit cost ratio (BCR), net present value (NPV), internal rate of return (IRR) dan paid back period.

Asumsi Perhitungan biaya investasi PLTM 15 Miliar per megawatt sehingga dengan kapasitas rencana terpasang adalah sebesar 1.279 MW maka biaya tersebut adalah sebesar 19.185 Miliar. Komponen komponen struktur dan peralatan PLTM antara lain:

1.Biaya Engineering

2.Peralatan dan pemasangan Hidromekanik

3.Peralatan dan Pemasangan Pipa pesat

4.Konstruksi bangunan sipil

5.Biaya kontingensi 
6.Biaya operasi dan pemeliharaan serta 7.PPN $10 \%$

Hasil teknis Perencanaan dasar PLTM Cibatu adalah sebagai berikut

1. Debit pembangkitan $=11.555 \mathrm{~m} 3 / \mathrm{det}$

2. Diameter penstock $=1.07 \mathrm{~m}$

3. Tebal pipa penstock $=8 \mathrm{~mm}$

4. Kehilangan tinggi $=1,22 \mathrm{~m}$ di saluran terbuka

5. MA di headpond $=\mathrm{El} .+555.71 \mathrm{~m}$

6. $\mathrm{TWL}=\mathrm{El} .+540.1 \mathrm{~m}$

7. Tinggi jatuh efektif $=11,88 \mathrm{~m}$

8. Jenis Turbin $=$ Kaplan

9. Kapasitas terpasang $(\mathrm{P})=1,279 \mathrm{MW}$

10. Energi tahunan $(\mathrm{AE})=7,964 \mathrm{GWh}$

\section{Kesimpulan dan saran}

a. Berdasarkan pada hasil analisa, maka beberapa hal yang dapat disimpulkan adalah Hasil analisa perencanaan didapatkan besaran pipa penstock dengan diameter dan ketebalan yang sama, dihasilkan kehilangan tinggi berkisar $0,734-1.22$ meter. Potensi energi tahunan yang dihasilkan adalah sebagai berikut:

- Tinggi jatuh effektif antara $11.555 \mathrm{~m}$

- Kapasitas terpasang antara 0,70-1.27 MW

- Energi tahunan yang dihasilkan antara 7.964$8.42 \mathrm{GWh}$

Komponen komponen bangunan PLTM cibatu meliputi:

- Bangunan pengambilan (roller gate, trashrack)

- Bangunan pembawa ( $w$ way, pipa pesat).

- Bangunan penenang (headpond)

- Bangunan pembuang (saluran tailrace).

- Sistem regulator (katup pintu).

- Rumah pembangkit (power house)

b. Peralatan mekanik dan elektrik:

Turbin kaplan beserta kelengkapanya (spiral case, draft tube dan wicket gate), generator $50 \mathrm{~Hz} 3$ fasa dengan 18 kutub, governor, speed increaser, dan aksesoris kelistrikan.

\section{Saran}

Berdasarkan uraian pembahasan, disarankan

beberapa

hal sebagai berikut:

1. Pada studi ini debit pembangkit untuk PLTM Cibatu dilakukan berdasarkan tinggi air di atas ambang mercu sabbo dam, untuk lebih mendapatkan hasil debit yang lebih optimal sebaiknya diuji juga untuk probabilitas debit andalan berdasarkan kurva durasi debit harian

2. Untuk mendapatkan diameter penstock yang paling optimal, disarankan untuk dicoba terhadap beberapa diameter untuk debit yang sama, sehingga akan didapatkan nilai konstruksi yang benar- benar optimal.

3. Analisa biaya konstruksi dalam studi ini belum dilakukan perhitungan secara mendetail hanya perkiraan kasar terhadap volume dan harga satuan, sehingga untuk mendapatkan hasil yang lebih detail sebaiknya disesuaikan dengan kondisi perencanaan.

4. Perhitungan ekonomi masih terus dilakukan oleh penulis untuk menyempurnakan kajian ini

\section{Daftar pustaka}

Anonim. 2006. Guidelines for National Greenhouse Gas Inventories. Switzerland: IPCC (International Panel In Climate Change).

Anonim. 1986. Standar Perencanaan Irigasi (Kriteria Perencanaan 02). Bandung : CV. Galang Persada.

Anonim. 1986. Standar Perencanaan Irigasi (Kriteria Perencanaan 04). Bandung : CV. Galang Persada.

Anonim. 2005. RETScreen ${ }^{\circledR}$ Engineering \& Cases Textbook. Kanada: RETScreen International.

Anonim, 1976. Engineering Monograph No. 20 Selecting Reaction Turbines. Amerika: United States Bureau of Reclamation.

Arismunandar A. \& Kuwahara S. 2004. Buku Pegangan Teknik Tenaga Listrik. Jakarta : PT Pradnya Paramita.

Arndt, R. E. A. 1998. Hydraulic Turbines. New York: St. Anthony Falls Laboratory University of Minnesota.

Chugoku Electric Power. 2009. Potential Survey for mini Hydropower Projects Utilizing Unexploted head on an irrigation canal network in east java state. Malang : Perum Jasa Tirta I.

Chow, Ven Te. 1997. Hidraulika saluran terbuka. Jakarta : Erlangga

Dandekar, MM \& K.N. Sharma. 1991. Pembangkit Listrik Tenaga Air. Jakarta : Universitas Indonesia.

Wiwik Widyaningsih ${ }^{1}$, Rispiningtati2, Pitojo Tri Juwono ${ }^{2}$,paper Kajian Peningkatan kapasitas PLTA LODOYO,Unibraw Malang 